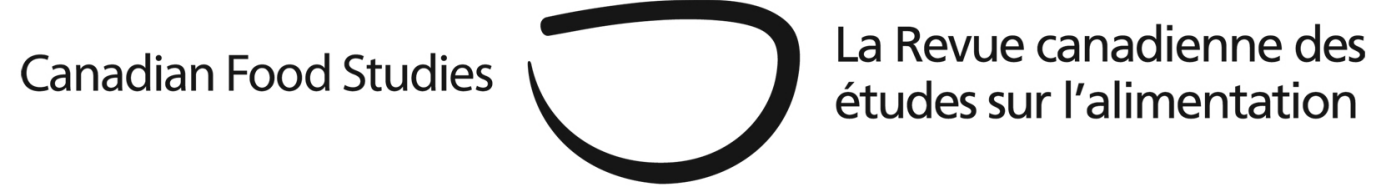

Section III

Global Food Trade

Special Issue: Mapping the Global Food Landscape

\title{
Food security and international trade: Risk, trust and rules
}

Sophia Murphy

PhD Candidate, Institute for Resources, Environment and Sustainability, University of British Columbia

The multilateral trade system today shapes the economy of almost every country of the world. The World Trade Organization (WTO) now has 160 members, and even the non-members must deal with the rules the WTO has established when they trade. The system is ubiquitous yet faces serious challenges. One of these is a challenge that in various guises and for different reasons has been present since it was instituted in 1995: food security. The most recent iteration of the challenge is a fight primarily between the U.S. and India over whether WTO rules should be reformed to accommodate the programmes the Indian government has introduced with its 2013 National Food Security Act (Kripke, this issue). The Indian government is buying food at administered prices from farmers to store and then later distribute through a public distribution system. This fight is important, as a simple scan of the specialist trade press shows. It has implications for all member states seeking to curb domestic food insecurity.

But there are other challenges to the trade system when it comes to food security that merit serious attention. Perhaps the most important of them is somewhat counterintuitive: the loss of confidence by low-income food deficit country governments (LIFDCs) that international trade should play a central role in their food security strategies as a result of the 2007-2008 global food-price crisis. 
Why counterintuitive? Because for several decades, many development economists have criticized trade - or rather, and more precisely, the trade liberalization programmes pursued under structural adjustment programs and its successors - for their failure to take into account the needs and priorities of developing countries (Chang, 2009; Helleiner, 1992; Rodrik, 2007; Stiglitz \& Charlton, 2005). So it is arguably a good thing for LIFDCs to see in such stark relief how poorly the international trade rules serve their needs. And it is a good thing, too, that these countries are looking to policies other than food imports to meet their food security objectives now that their confidence in international markets has been shaken (Wise, this issue). In this article I argue that rethinking how LIFDCs work with international markets in their food security strategies is overdue and welcome. At the same time, trade remains an important tool for food security, so the breakdown in trust is itself a problem to be resolved.

The global context

Developing countries' dependence on food imports has been increasing for decades. Figure 1 below shows just how dramatic the increase in LIFDCs' dependency on food imports has been over the past 15 years in particular. Note that the increase is measured here in the cost to developing countries in U.S. dollars; if measured by volume, the increase would be somewhat less dramatic. The trend, however, was already on an upward climb.

Figure 1: Agricultural Trade Balance of the Least Developed Countries, 1961-2011 ${ }^{1}$

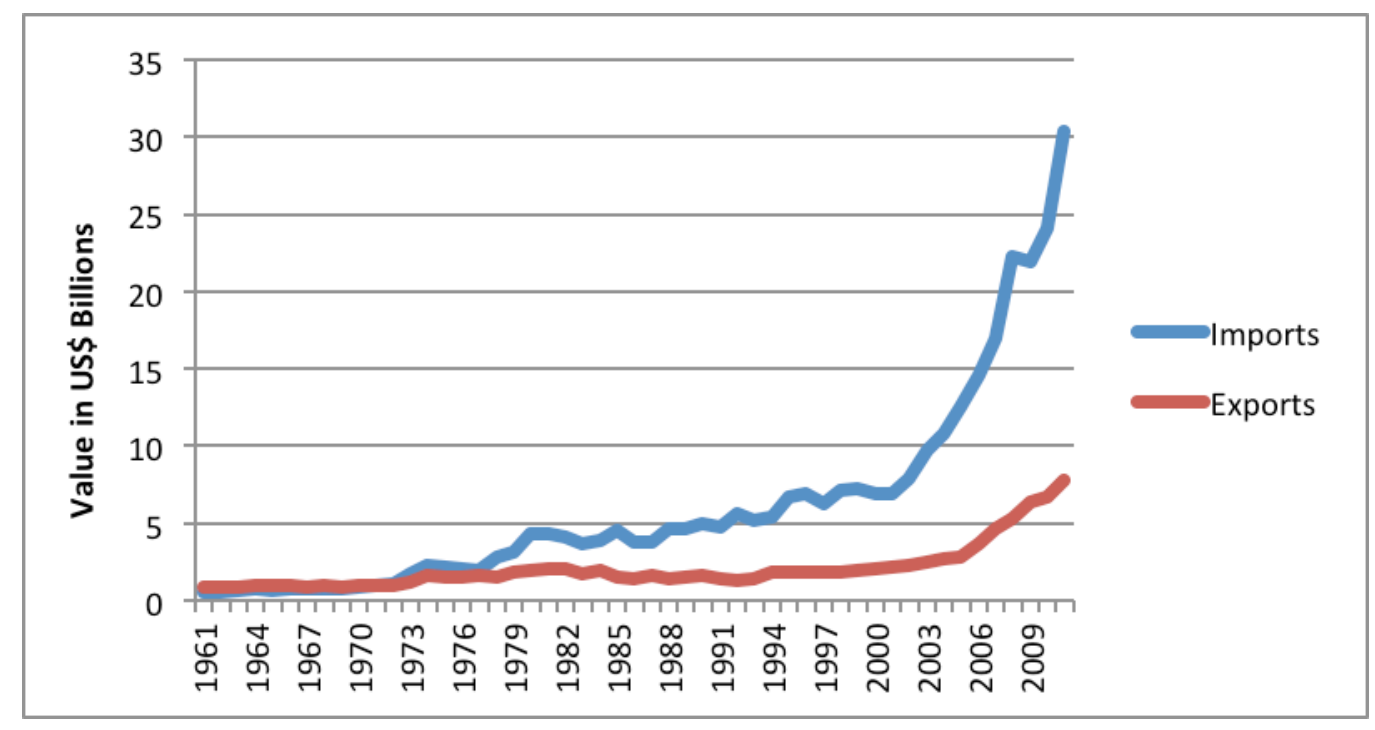

\footnotetext{
${ }^{1}$ Generated from FAOSTAT data.
} 
The World Bank, and many agricultural economists, have long promoted the idea of open international trade as a failsafe against domestic harvest failures, as a source of cheap food, and as way to replace "inefficient" domestic production with much more "efficient" (albeit often subsidized) production originating in industrial agricultural systems. ${ }^{2}$ These economists and development planners promised LIFDCs that sourcing cheap food from outside would free productive resources for higher value economic sectors. Those in favour of free trade also argued that it would provide consumers with more choices (i.e., more diversity of food), especially for those consumers whose income gave them greater purchasing power, and where rising incomes in general were sufficient to increase the choices available to all in the market place.

It could be said the policy advisors advocating trade liberalization were promising to address all four "pillars" of food security, as defined by the Food and Agriculture Organization (FAO): supply (more food and more variety of foods); access (cheaper for consumers because the competitive pool is widened); nutrition (because a greater diversity of foods is available through trade); and, stability (because food production globally is more stable than it is in any one country or region).

The practice did not live up to the promise. Environmental costs, such as pollution, natural resource exhaustion and biodiversity loss, were not counted in the analysis and models (Friedmann, this issue); nor were cultural food preferences (Clapp \& Dauvergne, 2011). For countries that eat traditional plant varieties that are susceptible to displacement by cheaper imports, free trade has reduced both biological and dietary diversity, even within species (see Lenzen et al., 2012, and for a Mexican case study of maize, see Fernández, Wise, \& Garvey, 2012). The free trade advocates ignored the role agriculture had played historically in stimulating broadly based economic growth (Chang, 2011; Dorward, 2013; Lipton, 1993; Mellor, 1995).

International markets are not the sum of all production globally. Rather, international markets are often residual, making them inherently unstable, except for those few crops where international trade is the norm. There are no international markets for a number of foods; among food staples, trade is heavily dominated by wheat and maize, with only a limited market for rice. Many food crops are hardly traded at all. Instead, much of the trade in the commonly traded grains is for animal feed. Markets tend to offer the best quality and lowest prices to the largest and richest buyers. Access depends on consumer purchasing power and that which is for sale in an international market is not automatically available to all. Using a deregulated market as the distribution mechanism means relative purchasing power dictates who has access to what food, something that should create unease in a global context where rates of inequality are increasing around the world, especially within countries but also across regions (Fuentes-Nieva \& Galasso, 2014).

\footnotetext{
${ }^{2}$ Note efficiency is a term that has, rightly, been critically examined by many scholars, including Princen (2005). Efficiency ignores many important externalities that generate significant costs that the market does not account for.
} 


\section{Rising dependence}

For developing countries as a whole, two distinct trends underlie their collective shift from net food exporters to net food importers. One trend is linked to a dramatic decrease in poverty in some parts of the world, especially in some parts of Asia and Latin America. Rising incomes in these countries have changed the volume and the composition of demand, in particular increasing the demand for meat (and linked to that, for animal feed) as well as for ingredients used in processed food, such as vegetable oils (Valdés \& Foster, 2012). The second trend is the increase in the import of staple food grains in some of the world's poorest countries. That trend dates back to the late 1970s, but has accelerated rapidly in recent years (see Figure 1) (Rakotoarisoa, Iafrate, Paschali, \& Elbehri, 2011).

Both trends are crucially important to understanding what is happening with regard to world food security. Both are problematic. The rising middle class dominates the numbers and the news. That demand masks deep inequalities within and among countries and is exacerbating unsustainable use of the planet's natural resource base, begging questions about how long the trend can persist and who will adjust their consumption and how, given the limits of the already stressed natural resource base (UNEP, 2012; Weis, this issue). There are also troubling questions linked to the dietary changes associated with this increased (feed and processed food) trade and to the rapid and dramatic increase in overweight and obese populations in developing countries (Clark, Hawkes, Murphy, Hansen-Kuhn, \& Wallinga, 2012; Hawkes, Blouin, Henson, Drager, \& Dubé, 2009).

But the second trend also deserves attention. There is a significant gap between the high importance of imports in LIFDCs' food supply (and thus their importance for consumer prices), and LIFDC governments' purchasing power in international markets, which is modest at best. Furthermore, and crucially, most LIFDCs still depend on agriculture to provide the lion's share of employment and to be an engine for economic activity in other sectors. Reliance on food imports as a strategy to keep food affordable is in direct tension with the need to raise productivity and to support plentiful, well-remunerated employment in agriculture.

\section{The food price crisis and the loss of trust}

These tensions came to a head when the food price crisis erupted in 2007-2008. There is widespread consensus - evident in G20 statements, UN reports and academic analysis - that the period of structural food surpluses and cheap food is at an end for now. Continuing population growth, concerns about the unsustainable nature of some agricultural production and climate change, are all factors in this analysis. The FAO predicts that price volatility will continue.

In the 1960s and 1970s, developing countries' food import bills varied mostly because domestic production was unstable, changing the volume of imports required year-on-year. 
During that period, international prices were relatively stable and had little effect on food import bills. This has changed. By 2012, Konandreas calculated that most (and in some cases all) of the total increase of developing countries' food import bills was due to international prices (cited in Valdés \& Foster, 2012, p. 13).

Dependence on volatile and unfair commodity markets is not new; it has been part of developing countries' reality for decades, pre-dating national independence. But the 2007-08 global food-price crisis put a new twist on the traditional commodity problem. Where the historic problem was the gradual, secular decline in primary commodity prices relative to other goods, the recent rise in commodity prices should have offered hope for countries that depend on commodity exports for their foreign exchange earnings, as many LIFDCs do. And, indeed, those revenues did increase. Farmers in LIFDCs, however, did not necessarily benefit from higher prices. That depended on the structure of the markets into which they sell, and how hard they were hit by the simultaneous increase in input prices (de Janvry \& Sadoulet, 2009).

The newer commodity problem is not the value of exports, though that still matters, but the cost of food imports, which are now a significant burden on LIFDC budgets. The international structures that set the path for greater dependency on staple food imports were reinforced by WTO rules, codified in the 1995 Agreement on Agriculture (AoA). The rules were meant to limit the extent of dumping on international markets through disciplines on agricultural subsidies. The rules were negotiated in the late 1980s and early 1990s when structural oversupply in international food markets was the norm (Margulis, 2014). The rules were meant to raise prices in international markets, and the Marrakech Ministerial Decision, passed in 1994 to accompany the AoA, was precisely to reassure LIFDCs that there would be financing to help pay for exports should prices rise (as was widely predicted). But the Marrakesh Ministerial Decision was never implemented and after a brief price spike in 1996, international food commodity prices returned to their long-standing downward trend, a trend that persisted until early in the 2000s (Clapp \& Cohen, 2009). The AoA focused on increasing market access through reducing tariffs and non-tariff barriers to trade and limiting certain kinds of subsidies, such as export subsidies and domestic support that increased with the volume of farmers' production. There were no rules to ensure exporters did not limit exports when supplies were low, a failing that deepened the 2007-08 price crisis (Sharma, 2011).

The AoA's narrow focus on how to manage surplus proved a liability when prices moved up and became more volatile in 2007-08 and after. The structures that many governments had put in place to manage scarcity had mostly been dismantled. Many of the state grain enterprises had gone bankrupt with the steady erosion of agricultural commodity prices during the 1980s and 1990s; others were undermined by poor management (Daviron \& Douillet, 2013; Murphy, 2009). This failure to anticipate a period of high and volatile prices was to prove very damaging to the trust governments had in international trade as a core guarantor of food security.

LIFDCs have lost confidence in international trade for (at least) two reasons: 1) their expectations were too high, in part because of the promises made by economic models and the 'Washington consensus' approach to development; and, 2) governments' understanding of what 
the threats and opportunities for food security are have shifted in the aftermath of the 2007-08 global food-price crisis. Developing-country governments have revised their food and trade policies and are looking again at approaches they had dismantled under economic structural adjustment programmes during the 1980s and 1990s (Galtier \& Vindel, 2013; Kripke, this issue).

The AoA was never really about food security. Achieving food security as a by-product of negotiations to reduce export subsidies and price floors in Europe and the U.S., while increasing market share for members of the Cairns Group, ${ }^{3}$ was always going to be a long shot.

Yet the present loss of trust is also dangerous. While WTO rules have over time exacerbated LIFDCs' growing dependence on food imports (Clapp, 2014; De Schutter, 2011), there is not really a "no trade" alternative. Without ignoring the very real disagreements over what the terms of trade should be and how to give priority to food security, trade is intimately, extensively and near-universally integrated into food systems around the world. Traded commodities provide livelihoods not just for the world's richest farmers, but also many of the poorest, and even poorer landless rural workers.

Trade rules pose a collective problem, one that requires a collective solution. Yet to restore confidence in international food trade will require new rules of some form. This is something WTO members have shown little willingness to discuss.

\section{What now? Research questions ahead}

Many civil society organizations (CSOs) and social movements welcome the current paralysis in WTO agricultural trade negotiations. Many of these groups have been critical of the AoA since it was adopted in 1994. They want to eradicate the WTO, not reform trade rules.

Developing country governments, on the whole, disagree with these CSOs. They want to pass the WTO Doha Agenda in some form though they dislike a number of the proposals. They say they want agreement on the Doha Agenda before considering any new proposals, on the grounds this will prevent some of the richer WTO members from cherry-picking the issues they deem "doable" (or too important to their export sectors to drop), and ignoring the rest, working on a plurilateral basis if necessary. This is in effect what the Trans-Pacific Partnership and the Trans-Atlantic Trade and Investment Partnership are about. As a result, the WTO is at an impasse.

Could governments consider, instead, a "lessons learned and gaps identified” exercise to establish a new basis for political agreement? This could revisit, in effect, the built-in review called for in the AoA text, and successfully implemented as the Analysis and Information Exchange in the first years after the AoA was adopted (between 1995 and1999). Trade in agricultural commodities has changed significantly in the last decade. Researchers should

\footnotetext{
${ }^{3}$ The Cairns Group is 20 agricultural exporting countries, including Australia, Brazil, Argentina, Indonesia and South Africa.
} 
document these changes (see, for example, Daviron \& Douillet, 2013) and consider their implications. In addition, researchers could consider:

1) Redefining food security as it is used in trade debates. Food security, particularly (but not only) in trade circles, is defined as the availability of a certain minimum number of calories per person, calculated at the national level. This shorthand has significant drawbacks. It ignores distribution and unequal purchasing power. It ignores intra-household and interclass dynamics. It misses entirely any understanding of the need for a varied diet to meet basic nutritional needs, which in turn ensures proper physical and mental development. The international system has spent ten important years expanding and refining our understanding of food security. How is the mounting evidence of unsustainable resource use in the production of food in many parts of the world factored into trade rules? What of the evidence from research on nutrition and the importance of trace elements in human development? What contribution can the Right to Food make, following the pioneering work of former Special Rapporteur on the Right to Food, Olivier de Schutter, and his team?

2) Revisiting the claims made about what trade can and cannot do for food security, and under what conditions. Food security challenges are many, complex and varied. The AoA distinguishes between developed, developing and least-developed countries (LDCs) but the categorization is too crude. Meanwhile, the 2008 draft negotiating text for the Doha Agenda created a chaotic mix of sub-groups (land-locked; Africa Group; small vulnerable economies, etc), each trying to carve out policy space for themselves. Might it be better to support flexible and nationally appropriate trade rules by using thresholds instead, linked to the size of market a particular country has in a particular commodity? How might this look in practice? At the same time, national policy space has to have limits in an interdependent world. What should those limits be? How might a system of trade rules manage to both respect varying levels of policy space while remaining workable?

\section{References}

Chang, H.-J. (2009). Rethinking public policy in agriculture: Lessons from history, distant and recent. Journal of Peasant Studies, 36(3), 477-515.

Chang, H.-J. (2011). Public policy and agricultural development. Hoboken: Taylor and Francis.

Clapp, J. (2014). Food and Hunger. In T. G. Weiss \& R. Wilkinson (Eds.), International organization and global governance. Oxford and New York: Routledge. 
Clapp, J., \& Cohen, M. J (Eds.). (2009). The global food crisis: Governance challenges and opportunities. Waterloo: Wilfred Laurier University Press.

Clapp, J., \& Dauvergne, P. (2011). Paths to a green world: The political economy of the global environment (2nd ed.). Cambridge, MA: MIT Press.

Clark, S. E., Hawkes, C., Murphy, S. M. E., Hansen-Kuhn, K. A., \& Wallinga, D. (2012). Exporting obesity: US farm and trade policy and the transformation of the Mexican consumer food environment. International Journal of Occupational and Environmental Health, 18(1), 53-64.

Daviron, B., \& Douillet, M. (2013). Major players of the international food trade and the world food security (No. 12). Wageningen. Retrieved from http://www3.lei.wur.nl/FoodSecurePublications/12n_Daviron\%20Douillet_Major\%20play ers\%20farm\%20policies.pdf

De Janvry, A., \& Sadoulet, E. (2009). The global food crisis and Guatemala: What crisis and for whom? World Development, 38(9), 1328-1339.

De Schutter, O. (2011). The World Trade Organization and the post-global food crisis agenda. Geneva: UN Special Rapporteur on the Right to Food.

Dorward, A. (2013). Agricultural labour productivity, food prices and sustainable development impacts and indicators. Food Policy, 39, 40-50.

Fernández, A. T., Wise, T. A., \& Garvey, E. (2012). Achieving Mexico's Maize Potential. Working paper No. 12-03 from Global Development and Environment Institute, Tufts University

Fuentes-Nieva, R., \& Galasso, N. (2014). Working for the Few. Oxford. Retrieved from https://www.oxfam.org/sites/www.oxfam.org/files/file_attachments/bp-working-for-fewpolitical-capture-economic-inequality-200114-en_3.pdf

Galtier, F., \& Vindel, B. (2013). Gérer l'instabilité des prix alimentaires dans les pays en développement. Paris: CIRAD/AFD.

Hawkes, C., Blouin, C., Henson, S., Drager, N., \& Dubé, L. (2009). Trade, food, diet and health. John Wiley \& Sons.

Helleiner, G.K. (1992). Trade policy, industrialization, and development. Oxford University Press. 
Lenzen, M., Moran, D., Kanemoto, K., Foran, B., Lobefaro, L., \& Geschke, A. (2012). International trade drives biodiversity threats in developing nations. Nature, 486(7401), 109-112.

Lipton, M. (1993). Urban bias: Of consequences, classes and causality. Journal of Development Studies, 29(4), 229-258.

Margulis, M. E. (2014). Trading out of the global food crisis? The World Trade Organization and the geopolitics of food security. Geopolitics, 19(2), 322-350.

Mellor, J. W. (1995). Agriculture on the road to industrialization. Johns Hopkins University Press.

Murphy, S. (2009). Strategic grain reserves in an era of volatility. Minneapolis: Institute for Agriculture and Trade Policy.

Princen, T. (2005). The logic of sufficiency. The MIT Press.

Rakotoarisoa, M. A., Iafrate, M., Paschali, M., \& Elbehri, A. (2011). Why has Africa become a net food importer: Explaining Africa agricultural and food trade deficits. Rome: Trade and Markets Division, Food and Agriculture Organization of the United Nations. Retrieved from http://www.fao.org/docrep/015/i2497e/i2497e00.pdf

Rodrik, D. (2007). One economics-many recipes: Globalization, institutions, and economic growth. Princeton: Princeton University Press.

Sharma, R. (2011). Food export restrictions: Review of the 2007-2010 experience and considerations for disciplining restrictive measures (No. 32). FAO Commodity and Trade Policy Research Working Papers. Rome: FAO.

Stiglitz, J. E., \& Charlton, A. (2005). Fair trade for all: How trade can promote development. Oxford: Oxford University Press.

UNEP. (2012). 21 Issues for the 21st Century. Nairobi: United Nations Environment Programme.

Valdés, A., \& Foster, W. (2012). Net Food-Importing Developing Countries: Who They Are, and Policy Options for Global Price Volatility; ICTSD Programme on Agricultural Trade and Sustainable Development; Issue Paper No. 43; International Centre for Trade and Sustainable Development, Geneva, Switzerland, www.ictsd.org. 